\title{
"Greening" our college libraries
}

\section{Complete the cycle of the three Rs}

\author{
by Kathleen Rickert
}

$\mathbf{P}$

rotecting the environment and concern for the scarce resources of the Earth are more crucial today than ever, yet our society appears to be moving in an increasingly dangerous direction Computers and the age of information technology have put expanded demands on our need for paper, printer cartridges, and computers. In this article, I wish to advocate for a "greener" mindset, and for recycling, reusing when possible, and reducing consumption.

In preparation for this article, I sent a survey in spring 2000 to 115 academic libraries in Minnesota and Wisconsin, inquiring about their recycling practices and the use of recycled products in their facilities. I received 75 replies, a return rate of about 65 percent. As I expected, Minnesotans recycle at an exceptionally high rate. In 1996, the latest year for which comparative figures are available, Minnesora's recycle rate was 44 percent, the highest in the nation. Wisconsin's recycle rate was 28 percent, with a stated goal of 60 percent by $2000 .^{x}$

\section{The paper trail}

Rather than creating the predicted "paperless society," the consumption of paper in the United States has increased fourfold over the past 20 years. ${ }^{2}$

Every day, more than 2 billion books, 350 million magazınes, and 24 billion newspapers are published in the United States. The average American uses 600 pounds of paper each year, and paper accounts for a third of the wasce disposed of in landfills, even after recycling, ${ }^{3}$

The bad news is that paper production is one of the mosc energy-intensive and polluting of all manufacturing industries, the process generating large amounts of solid waste and air and water pollution.

The good news is that Americans are recycling more than ever. The American Forest and Paper Association estimates that the U.S. paper industry recovers for recycling 45 percent of all paper Americans use, up from just 15 percent in 1988 . Their new goal for 2000 was 60 percent.

Of those libraries that responded to $\mathrm{my}$ survey, 88 percent recycled office paper, and an equal percentage reported that they also recycled discarded newspapers.

Recycling our waste paper is just one figure in the recycling equation-using recycled paper is another. Recycled paper-once rejected for being of uneven quality, grayish, or spotted-today meets the highest technical standards, sometimes even exceeding comparable virgin paper (or paper with no discernible postconsumer content). Yet according to my survey of academic libraries, only about half reported use of paper with recycled content. 
Recycled paper-once rejected for

being of uneven quality, grayish,

or spotted-today meets the

highest technical standards,

sometimes even exceeding

comparable virgin paper . . .

In academic libraries, the expanded use of the Internet and the Web to provide academic resources has had a tremendous impact on paper use and printing. With the in creased availability of journals online and in full text in the latter part of the past decade, nearly all libraries reported an explosion in paper consumption. No longer forced to stand at a copy machine while it hungrily gobbled up their change, patrons can now print what they find, just in case they need it, all for free.

\section{Printer cartridges}

Laser toner cartridges are easily recycled, ${ }^{6}$ and using recycled cartridges is an economically and environmentally sound choice. Recyclers will accept used cartridges, often providing a box and postage-pard shipping label. An ad for one such cartridge recycler states that cartridges are tested for stress and wear before and after the re-manufacturing process. Those in good repair are filled and resold, usually at about 30 percent less than a new cartridge Those in poor condition are dismantled, us able parts removed, and the plastic crushed and melted for use in other products. Of the libraries responding to my survey, 73 percent recycled all or some of their used printer cartridges, while 51 percent purchased recycled printer cartridges

\section{Computers}

Almost 50 million computers are purchased in the United States each year. ${ }^{7}$ Falling prices make computers cheaper to replace than to repair, while the porential use for older com puters is shrinking. Fewer people want older computers, and even schools and nonprofits can now afford the newest models. The rapid manufacture and consumption of computers is cause for environmental concern when considering the amounts of energy, photochemicals, acids, hydrocarbon-based solvents, and other resources that go into production. One study found that the process of manufacturing one $\mathrm{PC}$. produced three pounds of waste for every pound of product.

Computers are also creating a significant waste-disposal problem in the United States, where four computers end up in the landfill for every one that is recycled. ${ }^{9}$ A study at Carnegie Mellon University claimed that 3 million computers went into landfills in $1997,{ }^{10}$ while the National Safety Council put the figure at 20 million in 1999 . They estimate that this figure will grow to 61 million by $2007 .{ }^{11}$

The environmental concerns regarding computer recycling begin with plastics. The National Safety Council considers plastic the most challenging material to recycle from electronic equipment. ${ }^{12}$ Because electronics often contain several types of plastic, recyclers often don't care to sort through them. Also, some plastics contain chemicals that can be toxic when exposed to the heat of the recycling process. And new plastic is so inexpensive, rhere is little incentive for manufacturers to risk contaminating their products with lower, unsorted grades.

A second environmental concern with discarded computers is the monitor. Televisions and computer monitors contain cathode ray tubes (CRTs), which each contain four-roseven pounds of lead to protect the user from radioactivity. Disposing of it is the biggest expense for a recycler. In Minnesota, CRT's have become the biggest source of lead in the state's waste stream, second only to car

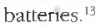

Computers also have considerable environmental impact in terms of the energy that it rakes to run them in day-to-day use. Hardly a college or library functions today without desktop computers. One estimate in the late 1990s reported that computer use would account for ten percent of all energy consumption in the year $2000 .{ }^{16}$ Turning off unused computers would certainly reduce power con sumption

\section{Taking steps forward}

If your library is not already using recycled paper products, please look into purchasing them. High-quality printer paper, stationery, envelopes, and note pads are available at 
prices less than or comparable to those with little or no recycled content. If you are already using recycled paper, consider using one with a higher postconsumer content.

The federal government requires the use of not less than 30 percent postconsumer content in its offices, and many states requires 20 percent or more. ${ }^{15}$ The higher the postconsumer content, the higher the percentage of materials recovered by recycling and the less virgin content.

Look on the packaging for the international symbol for recycling (the ring of arrows) and a statement of postconsumer content. To locate a supplier of recycled paper products, consult your institution's purchasing department, or use any Internet search engine and type the phrase, "recycled paper."

Place recycling receptacles in convenient and obvious places. Ler your students know that "We Recycle." Consider purchasing a duplexer, which will allow a laser printer to print on both sides. Encourage students and your co-workers to use paper printed on one side for noretaking, scrarchpaper, and in desktop printers. One respondent to my survey commented that her library donates paper printed on just one side to a local nonprofit.
Teach your students how they can save paper by printing smartly. By using the "marked records" function available on many databases, they can avoid printing out long lists of citations By using "print preview" when printing from the Internet or other online documents, they can princ just the pages they need.

Many of my colleagues feel that students would think twice before hitting the "print" button if they had to pay for every sheet of paper they printed. Of the college libraries responding to my survey, 23 percent said that they charged for printing, and indicated a cost ranging from 4 to 11 cents per page. A few noted that this "may happen in the future" and that "we are currently considering this. One college allows students 500 free pages per year and charges for printing over this amount. The technology exists to network printers to student accounts, and we may see more charging in the future.

At my own college, I was told that we return used toner cartridges for recycling, but that we do not purchase recycled products In an effectuve recycling system, a consumer would recycle items that could be recycled, then purchase goods manufactured from these recycled products. Colleges could help close

\section{More information on recycling}

- American Forest \& Paper Associa-

tion: Publications and information from the nacional trade association of the forest, paper, and wood pulp industry. http://www. afandpa.org

- Recycled Paper Coalition: Organization of more than 260 businesses and nonprofits atrempting to address environmental problems. Site indudes many publications, including the excellent Recycled Paper Factbook in prlf format, and an extensive listing of links to organizations, businesses, and govemment sites. hitp//www papercoalition.org/

- Buy Recycled Business Alliance: Businesses and nonprofits committed to increasing the use of recycled-content products. http://brba.nrc-recycle.org/

- Conservatree: Information on new technologies, advocacy, and legislative issues. http://www.conservatree.com
- Environmental Systems of America: Inforntation on green shopping, recycling resources, recycling myths, FAQs, and links to other organzations. http:// www.envirosystemsinc.com

- Grass Roots Recycling Network: Founded in 1996 by leaders of the Sierra Club, this network of community-based activists, advocating environmentally sound policies and practices with regard to waste http //www grrn org

- GreenBiz.com: Includes articles and information on consumer attitudes toward green issues, waste-saving strategies, recycled and environmentally preferred products, and more. http://www. greenbiz.com

- Iasertone International: Information on recycled printer cartridges. http:// www.laser-tone.com 


\section{When better computers are built,}

\section{they will be kept out of the waste}

stream longer. Consumers should

\section{be demanding that companies do just that.}

the recycling loop by purchasing recycled cartridges.

Computers are the most difficult to tackle. If I can go longer without an upgrade, I know I will consume less. However, slower, older models make it impossible for me to run the programs I need to do my job in the technology-driven field of librarianship.

Harmful as computer manufacturing and recycling can be, I am hopeful about the future of the industry. Japan, the Netherlands, and other northern European countries are passing "take-back" legislation that requires companies to take back and recycle products as they are discarded. "G "Green" computer design technology exists to reduce resources consumed and wasted, to make the manufacturing process cleaner, to minimize the energy computers consume, and to make components recyclable. When better computers are built, they will be kept out of the waste stream longer. Consumers should be demanding that companies do just that.

Conservation and environmentalism is not always clear-cut when information is the commodity, as it is in libraries. The tools of our trade demand that we use paper, toner, computers, and electricity. I urge those in my profession to consider the ideas I have presented and to do what they can. Complete the cycle-reduce, reuse, and recycle.

\section{References}

1. Deborah Strong, Recycling in America: A Reference Handbook, $2^{\text {nd }}$ ed. (Santa Barbara, CA: ABC-CLIO, 1997).

2. American Forest and Paper Association, "U S. paper recycling: an environmental success, " retrieved June 2, 2000, from the Web at hip:// wow afandpa.org.

3. Strong, Recycling in America A Reference Handbook

4. Environmental Defense Fund Reports 2000. "Make that recycled coated freesheet paper," rerrieved June 2, 2000, from the Web at http:// wow environmentaldefense.org/pubs/Reports.
5. American Forest and Paper Association

6. S. Bass 1996. "Cash for trash: turn your printer cartridges into cash," PC World, 14:314t. Retrieved April 29, 2000, from InfoTrac dacabase (Expanded Academuc ASAP) on the web at http:/infotrac galegroup.com/irweb/clic_stkate.

7. National Public Radio (NPR) "All Things Considered," October 30, 1999 (transcript). Retrieved Now. 1, 1999, from the Lexis-Nexis database (Academic Universe) on the Web at htp://www lexisnexis, com/universe.

8. Lee Goldberg, "The advent of 'green' computer design," Computer (1998): 31:16-19.

9. Environmental Systems of Amenca

10. Mark Fearer, "Turn garbage into gold," Computer Life (1998). 5.42+. Retrieved Nov. 1, 1999 , from InfoTrac database (Expanded Academic ASAP) on the Web at hitp://infotrac.galegroup.com/itweb/ clic stkate.

11. Susan Schmickle, "Aftershock of the technology boom," Star-Tribune (Minneapolis). Retrieved Nov. 1, 1999, from the Web at hitp:// www.startribune.com.

12 Ibid

13. Ibid.

14. Lee Goldberg, "The advent of 'green' computer design."

15. Conservatree. 2000. "Environmentally sound paper overview: Essential issues." Retrieved June 2. 2000 from the Web: htip:// www.conservatree.com/learn/Essential_ Issues/.

16. National Public Radio (NPR), 1999.

("ACRL 2002 Awards Progntm" cont. from page 823)

- K. G. Saur Award for Best Article in College \& Researcb Libraries (sponsored by $R$ R. Bowker/K. G. Saur): $\$ 500$ cash award for the most outstanding article published in CERL during the preceding volume year.

- Instruction Section Publication of the Year Award. Recognizes an outstanding publication related to instruction in a library environment published in the last two years

\section{Contact ACRL for details}

If you would like more information about the ACRL 2002 Awards Program, visit our Web page at http://www.ala.org/acrl.award2.htrnl or contact ACRL Program Assistant Stephanie Sherrod, at (800) 545-2433 ext.2515, e-mail: ssherrodoala.org.

We welcome your nominations and look forward to celebrating achievements in academic librarianship in 2002. 


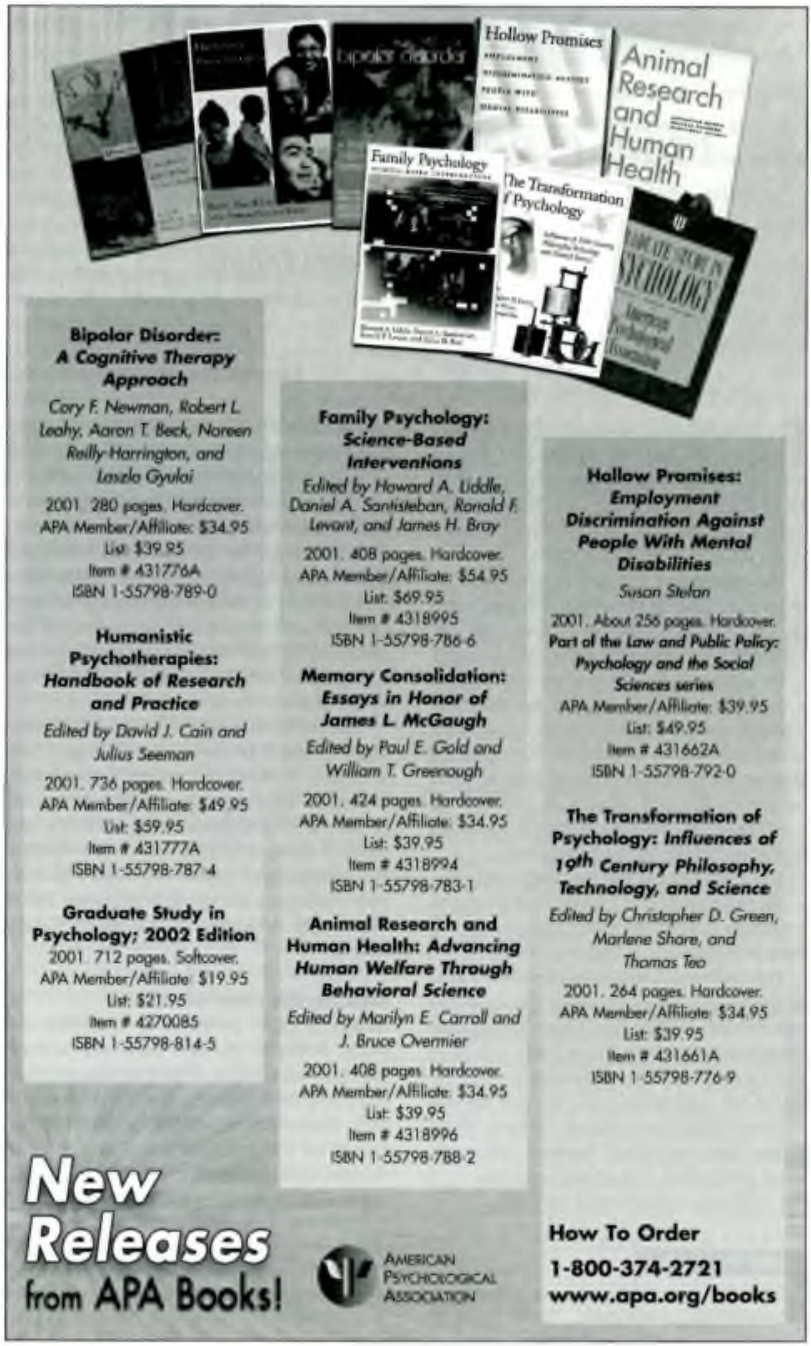

